\title{
KEBIJAKAN SISTEM ZONASI PADA PENERIMAAN PESERTA DIDIK BARU (PPDB) DI YOGYAKARTA
}

\author{
M. Hanif Satria Budi \\ budisatria1992@gmail.com \\ Institut Agama Islam Faqih Asy’ari Kediri, Indonesia
}

\begin{abstract}
The acceptance of new students (PPDB) using the zoning system was first implemented in Yogyakarta in 2018/2019. This zoning system aims to equalize education and improve the quality of education. This research was conducted to find out how the zoning system policy in Yogyakarta city under the auspices of the Yogyakarta City Education Office. This research uses qualitative approach with case study method. The results of the study showed that the zoning system in Yogyakarta has changed from the previous year. In 2019/2020 the zoning system provides a $10 \%$ chance of superior seeds, $30 \%$ of school zones, $10 \%$ of poor learners, $40 \%$ of quality pathways, $5 \%$ of out-of-school zoning pathways, and $5 \%$ of special pathways such as prospective learners whose parents moved from other regions to Yogyakarta. With this zoning system, the whole community has the opportunity to get a good quality education.
\end{abstract}

Keywords: Policy Implementation, Zoning System,

\begin{abstract}
Abstrak
Penerimaan peserta didik baru (PPDB) menggunakan system zonasi pertama kali diterapkan di Kota Yogyakarta pada tahun 2018/2019. System zonasi ini bertujuan untuk pemerataan pendidikan dan meningkatkan kualitas pendidikan. Penelitian ini dilakukan untuk mengetahui bagaimana kebijakan system zonasi di Kota Yogyakarta di bawah naungan Dinas Pendidikan Kota Yogyakarta. Penelitian ini menggunakan pendekatan kualitatif dengan metode studi kasus. Hasil kajian tersebut menunjukkan bahwa jalur system zonasi di Kota Yogyakarta mengalami perubahan dari tahun sebelumnya. Pada tahun 2019/2020 sistem zonasi memberikan peluang $10 \%$ bibit unggul, 30\% zona sekolah, $10 \%$ peserta didik tidak mampu, 40\% jalur mutu, 5\% jalur luar zonasi sekolah, dan 5\% jalur khusus seperti calon peserta didik yang orang tuanya berpindah tugas dari daerah lain ke Yogyakarta. Dengan adanya system zonasi ini seluruh masyarakat memiliki kesempatan untuk mendapatkan kualitas pendidikan yang baik.
\end{abstract}

Kata Kunci : Implementasi Kebijakan, Sistem Zonasi, 


\section{Pendahuluan}

Sesuai dengan UUD 1945 pasal 31 ayat 1 bahwa "setiap warga Negara berhak mendapatkan pendidikan”. Sangat jelas bahwa setiap warga Negara mempunyai hak yang sama untuk mendapatkan pendidikan yang layak. Namun kenyataannya sekarang masih belum layak. Kita lihat bagaimana pendidikan di Desa dengan Kota. Masih terjadi ketimpangan. Banyak sekolahsekolah di Desa sarana prasarana penunjang pendidikan masih sangat kurang. Berbanding terbalik dengan sekolah-sekolah yang ada di kota memiliki sarana prasana pendidikan yang maju dan modern.

Fenomena ini mengakibatkan banyak anak-anak di desa yang bersekolah di daerah kota yang memiliki sarana prasana yang maju dan modern, meskipun jarak dari rumah ke sekolah puluhan kilometer. Namun tidak menutup kemungkinan kurangnya pemerataan pendidikan juga ada di kota dengan kasus yang berbeda. Misalnya anak yang seharusnya masuk usia sekolah, mereka tidak bisa sekolah karena harus bekerja membantu orangtua untuk kebutuhan ekonomi. Kesenjangan tidak hanya dilihat dari segi sarana dan prasaran pendidikan, tapi juga dilihat dari masyarakat yang kurang mampu dan masyarakat terpencil.

Salah satu usaha pemerintah untuk memajukan pendidikan di Indonesia adalah dengan program pemerataan pendidikan. Salah satunya kebijakan PPDB dalam system zonasi. System zonasi ini menjadi salah satu gagasan dari pemerintah untuk memberikan pendidikan yang sama kepada masyarakat dengan pemerataan pendidikan. Dengan pemerataan pendidikan ini, maka tidak ada yang namanya sekolah unggulan yang sering kita dengar dikalangan masyrakat. Semua lapisan masyarakat terutama yang ada di pelosok bisa mendapatkan pendidikan yang baik dan sarana prasarana yang memadai. Berdasarkan Permendikbud No 51 Tahun 2019 tentang Penerimaan Pserta Didik Baru (PPDB) adalah penerimaan peserta didik baru untuk jenjang taman kanak-kanak, sekolah dasar, sekolah menengah pertama, dan sekolah menengah atas, sekolah menengah kejuruan atau bentuk lain yang sederajat.

Penerapan kebijakan system zonasi dalam PPDB diatur dalam Permendikbud No. 14 Tahun 2018. Dalam peraturan 
tersebut disebutkan bahwa sekolah wajib menerima paling sedikit $90 \%$ peserta didik yang berdomisili di zona sesuai peraturan pemerintah. Dengan demikian bahwa sekolah menerima peserta didik yang tempat tinggalnya dekat dengan sekolah. Dengan kata lain skema zonasi memungkinkan siswa memilih bersekolah di dekat rumahnya ${ }^{1}$.

Pemerataan pendidikan merupakan persoalan sistem pendidikan yang mampu memberikan kesempatan seluasluasnya kepada seluruh warga negara untuk memperoleh pendidikan. Permasalahan ini terjadi disebabkan karena kurangnya sarana dan prasarana penunjang pendidikan. Banyak sekolah-sekolah di desa-desa atau di wilayah tertentu yang kekurangan sarana prasarana penunjang kegiatan pembelajaran, hal ini berbanding terbalik dengan sekolah-sekolah di kota yang memiliki sarana prasarana sangat maju. Fenomena demikian inilah yang menimbulkan kesenjangan antara sekolah berlabel favorit dengan sekolah-sekolah lain yang berlabel non favorit atau tidak unggul. Sekolah yang berlebel favorit terkesan hanya bisa dinimakti oleh siswa yang memiliki kemampuan akademis serta kemampuan secara financial, sehingga kesenjangan ini dapat berdampak pada sekolah, ada sekolah yang memiliki banyak siswa ada juga sekolah yang kekurangan siswa, jika kesenjangan ini terjadi secara terus-menerus akan menimbulkan dampak yang tidak baik pada dunia pendidikan berskala nasional. $^{2}$

Fenomena tersebut mengakibatkan peserta didik yang memiliki potensi tidak mau bersekolah di sekolah yang kurang sarana prasarana, peserta didik akan cenderung memilih sekolah favorit yang memiliki sarana prasarana memadai walaupun jarak dari tempat tinggalnya sangat jauh. sebenarnya masih ada beberapa sekolah di wilayah perkotaan yang mengalami

1 Mandic, S., Et.Al, "I Wanted To Go Here": Adoloescents' Perspectives on Shool Choice, (Journal of School Choice, 12 (1), 2017) : hal. 98-122

2 Bintoro, Ratih Fenty A. 2018. "Persepsi Masyarakat Terhadap Implementasi Kebijakan Zonasi Sekolah dalam Penerimaan Peserta Didik Baru (PPDB) Tingkat SMA Tahun Ajaran 2017/2018 di Kota Samarinda. Jurnal Riset Pembangunan. Vol. 1 No.1 
kesenjangan pemerataan pendidikan meskipun dengan kasus yang berbeda, misalnya anak usia belajar namun tidak bersekolah karena harus membantu orang tuanya bekerja karena tergolong pada tingkat ekonomi lemah. Fenomena kesenjangan tersebut cukup kasat mata, kesenjangan pemerataan pendidikan tidak hanya pada sarana dan prasarana penunjang kegiatan pembelajaran tetapi juga didasarkan oleh masyarakat yang kurang mampu dan masyarakat terpencil.

Walaupun faktanya sudah banyak program pemerintah yang terus bergulir untuk menangani permasalahan ini misalnya program wajib belajar 9 tahun, pemberian program beasiswa, atau Bantuan Operasional Sekolah (BOS). Upaya pemerintah dalam mempercepat penanggulangan kesenjangan tersebut salah satunya dengan membuat suatu kebijakan baru dalam PPDB saat ini. Berdasarkan Permendikbud No 51 Tahun 2019 Penerimaan Peserta Didik Baru (PPDB) adalah penerimann peserta didik untuk jenjang taman kanak-kanak, sekolah dasar, sekolah menengah pertama, dan sekolah menengah atas, sekolah menengah kejuruan atau bentuk lain yang sederajat.

Salah satu upaya pemerintah dalam memajukan dunia pendidikan nasional adalah dengan program pemerataan pendidikan, yaitu menerapkan kebijakan PPDB yang didalamnya mengatur mangenai sistem zonasi sesuai dengan peraturan Menteri Pendidikan dan Kebudayaan No 17 Tahun $2017^{3}$ yang mengatur mengenai sistem zonasi. Sistem zonasi menekankan pada jarak atau radius antara rumah peserta didik dengan sekolah, sehingga siapa yang lebih dekat jarak tempuhnya antara tempat tinggal dengan sekolah, maka peserta didik tersebut lebih berhak untuk medapatkan layanan pendidikan di sekolah tersebut. Meningkatkan kualitas pendidikan salah satunya denga cara upaya reformasi sekolah yaitu dengan menggunakan sistem zonasi. Sistem zonasi diharapkan mampu mempercepat dan menciptakan pemerataan pendidikan yang berkualitas, karena peserta didik yang memiliki prestasi mau tidak mau harus mendaftar sekolah yang memiliki

${ }^{3}$ Wulandari, Desi, dkk. 2018. "Pengaruh Penerimaan Peserta Didik Baru Melalui Sistem Zonasi Terhadap Prestasi Belajar Siswa". Jurnal Kultur Demokrasi. Vol 5 No 9 
radius terdekat dari tempat tinggalnya, sehingga siswa berprestasi tidak hanya berkumpul di sekolah favorit saja.

Selain itu kebijakan ini diharapkan mampu menyinergikan tripusat pendidikan, yaitu sekolah, masyarakat, dan keluarga untuk menyadarkan bahwa tanggung jawab pendidikan merupakan tanggung jawab bersama tidak hanya satu pihak saja. Namun hal terpenting yaitu peserta didik mendapatkan layanan pendidikan yang terdekat dari tempat tinggal. Selain itu dampak dari sistem zonasi yaitu memacu peningkatan kualitas tenaga pendidik dan kependidikan, karena sekolah yang menerima peserta didik berprestasi mau tidak mau kualitas pengajar di sekolah tersebut harus ditingkatkan agar dapat membimbing peserta didik dengan baik. Sehingga tidak ada penumpukan sumber daya manusia yang berkualitas dalam satu wilayah tertentu.

Namun pada kenyataannya banyak aduan dari orang tua peserta didik karena kerja keras anak untuk mendapatkan nilai UN sia-sia, karena anak tidak dapat bersekolah di sekolah favorit yang radiusnya jauh dari tempat tinggal, atau kasus lain seorang anak dari keluarga tidak mampu terpaksa bersekolah di sekolah yang membutuhkan biaya mahal karena sekolah yang minim biaya memiliki jarak yang jauh dari tempat tinggal. Dalam implementasinya sejak tahun 2018/2019 kota Yogyakarta telah menerapkan sistem zonasi. Masalah-masalah yang telah teruraikan tersebut juga dialami di kota Yogyakarta dalam penerimaan peserta didik baru. Kota Yogyakarta memiliki 89 SDN dan 16 SMPN. Namun faktanya tidak semua sekolah berlabel Negeri sejahtera, ada beberapa di wilayah Yogyakarta sekolah Negeri tetapi minim sarana prasarana dan sedikit jumlah peserta didik yang bersekolah disekolah tersebut.

Sistem zonasi menekankan pada jarak atau radius antara rumah peserta didik dengan sekolah, sehingga siapa yang lebih dekat jarak tempuhnya antara tempat tinggal dengan sekolah, maka peserta didik tersebut lebih berhak untuk medapatkan layanan pendidikan di sekolah tersebut. Meningkatkan kualitas pendidikan salah satunya denga cara upaya reformasi sekolah yaitu dengan menggunakan sistem zonasi. Sistem zonasi diharapkan mampu mempercepat dan menciptakan pemerataan pendidikan yang berkualitas, karena peserta didik yang memiliki 
prestasi mau tidak mau harus mendaftar sekolah yang memiliki radius terdekat dari tempat tinggalnya, sehingga siswa berprestasi tidak hanya berkumpul di sekolah favorit saja. Kebijakan dalam sistem zonasi menciptakan pemerataan, siswa yang memiliki prestasi tidak berkumpul disekolah yang berlebel favorit saja, karena berdasarkan mekanisme sistem zonasi siswa harus mendaftar sekolah yang jaraknya dekat dari tempat tinggal, dan tidak bisa mendaftar seklah yang jaraknya jauh dari tempat tinggal walaupun berlabel favorit. ${ }^{4}$

Dengan adanya sistem zonasi diharapkan pemerataan pendidikan dapat terwujud, dapat menghemat waktu karena jarak sekolah dan tempat tinggal dekat sehingga dapat menghemat biaya transportasi sehingga tidak ada lagi segresi pendidikan. Namun dilain sisi PPDB dengan sistem zonasi manjadi masalah tersendiri untuk tenaga pengajar/pendidik. Guru/pendidik di sekolah negeri yang biasanya mengajar peserta didik dengan akademik tinggi kini harus mengajar peserta didik yang memiliki berbagai timgkat kecerdasan atau kemampuan, sehingga guru dituntut untuk lebih kreatif atau membutuhkan metode dan cara yang ekstra dari biasanya.

\section{Metode}

Penelitian ini bertujuan untuk menganalisis sistem zonasi di kota Yogyakarta pada tahun 2019/2020. Penelitian ini menggunakan pendekatan kualitatif dengan metode studi kasus dengan pengambilan data menggunakan wawancara, dokumen, dan observasi. Alasan peneliti menggunakan rancangan studi kasus agar peneliti mendapatkan informasi yang sebenarbenarnya karena secara langsung peneliti hadir dilapangan. Karena di sini peniliti sebagai instrument kunci dalam mengumpulkan data baik dari dokumentasi, observasi, dan wawancara. Sesuai dengan yang dikatakan John W. Creswell bahwa peneliti sebagai isntrumen kunci (research as key instrument) para peneliti kualitatif mengumpulkan sendiri data melalui dokumentasi, observasi perilaku, atau wawancara

4 Abidin, Muhammad Zainal dan Asrori. 2018. "Peranan Sekolah Kawasan Berbasis Sistem Zonasi dalam Pembentukan Karakter di SMP Negeri 15 Kedung Cowek Surabaya". Jurnal Pendidikan Islam. Vol. 7 No. 1 
dengan para partisipan ${ }^{5}$. Lokasi penelitian ini bertempat di Dinas Pendidikan kota Yogyakarta jl. Hayam Wuruk No 11, Tegal Panggung, Kec. Danurejan, Kota Yogyakarta.

\section{Pembahasan}

Menurut Grindle implementasi kebijakan sesungguhnya tidak hanya sebatas pada mekanisme penjabaran keputusan politik ke dalam prosedur rutin melalui saluran birokrasi, tetapi berkaitan dengan masalah konflik, yaitu siapa memperoleh apa dalam suatu kebijakan ${ }^{6}$. Kebijakan pendidikan merupakan kebijakan public yang digodok oleh lembaga yang berwenang dan disahkan oleh Presieden. Kebijakan dalam pendidikan penting karena pendidikan dianggap sebagai suatu hal strategis sebagai penentu kualitas sumber daya manusia sebuah bangsa. kebijakan publik dibidang pendidikan ini dapat diartikan sebagai sebuah keputusan yang diambil oleh pemerintah dan aktor yang ada di luar pemerintah yang mempertimbangkan faktor-faktor yang mempengaruhinya untuk diambil keputusan yaitu dilaksanakan atu tidak dilaksanakan suatu kebijakan itu. Kebijakan publik dibidang pendidikan ini meliputi kurikulum, sumber daya, sarana prasaran, serta hal lainnya yang berhubungan dengan pendidikan. ${ }^{7}$

Menurut Anderson sebagimana yang dikutip Arif Rohman dan Teguh Wiyono, kebijakan (policy) diartikan sebagai suatu arah tindakan yang bertujuan, yang dilaksanakan oleh pelaku kebijakan di dalam mengatasi suatu masalah atau urusan-urusan yang bersangkutan. ${ }^{8}$ Kebijakan public salah satunya adalah kebijakan pendidikan H.A.R Tilaar dan Riant Nugroho dalam buku menjelaskan bahwa Kebijakan pendidikan adalah keseluruhan proses dan hasil perumusan langkah-langkah strategis pendidikan yang dijabarkan dari visi, misi pendidikan,

5 John W. Creswell, Research Design: Pendekatan Metode Kualitatif, Kuantitatif, dan Campuran. (Yogyakarta: Pustaka Pelajar, 2017), hal. 248

${ }^{6}$ Rusdiana. Kebijakan Pendidikan Dari Filosofi ke Implementasi. ( Bandung: CV Pustaka Setia, 2015), hal. 132

7 M. Hasbullah, Kebijakan Pendidikan (Jakarta: RajaGrafindo Persada, 2015), 59

8 Arif Rohman dan Teguh Wiyono, Education Policy In Desentralization Era (Yogyakarta: Pustaka Pelajar, 2010), hal. 2 
dalam terwujudnya tujuan pendidikan dalam suatu masyarakat untuk kurun waktu tertentu. ${ }^{9}$

Sedangkan konsep kebijakan pendidikan menurut Mudjia Raharjo yang dikutip dari Duke dan Canady yaitu: 1) kebijakan sebagai penegasan maksud dan tujuan, 2) kebijakan sebagai sekumpulan keputusan lembaga yang digunakan untuk mengatur, mengendalikan, mempromosikan, melayani, dan lainlain pengaruh dalam lingkup kewenangannya, 3) kebijakan sebagai panduan tindakan diskresional, 4) kebijakan sebagai strategi yang diambil untuk memecahkan masalah, 5) kebijakan sebagai pelaku yang bersanksi, 6) kebijakan sebagai norma perilaku dengan ciri konsistensi dan keteraturan dalam beberapa bidang tindakan substansif, 7) kebijakan sebagai keluaran system pembuatan kebijakan, dan 8) kebijakan sebagai pengaruh pembuatan kebijakan, yang meunnujuk pada pemahaman khalayak sasaran terhadap implementasi system. ${ }^{10}$

Proses Implementasi Kebijakan

Implementasi kebijakan sering dikaitkan dengan proses administrative, yang di dalamnya ditemukan banyak proses dan aktivitas organisasional dalam proses dan pendekatan yang dilakukannya. Menurut Gupta proses implementasi kebijakan adalah tahapan yang dilakukan setelah suatu kebijakan diadopsi (adioted) atau disahkan oleh pihak-pihak yang memiliki otoritas dalam kebijakan bersangkutan. ${ }^{11}$

Berdasarkan paparan di atas, dapat disimpulkan bahwa proses implementasi kebijakan dibuat oleh beberapa pihak yang memiliki kepentingan dan kebijakan ini juga dipengaruhi oleh factor politik, ekonomi dan social baik secara langsung ataupun tidak langsung.

Menurut Lineberry ada beberapa elemen dalam proses

${ }^{9}$ H.A.R Tilaar dan Riant Nugroho, Kebijakan Pendidikan: Pengantar Untuk Memahami Kebijakan Pendidikan dan Kebijakan Pendidikan sebagai Kebijakan Publik (Yogyakarta: Pustaka Pelajar, 2010), hal. 140

10 Mudjia Rahardjo, Pemikiran Kebijakan Pendidikan Kontemporer (Malang: UIN Maliki Press, 2010), 3

11 Gupta K. Dipak. Analyzing Public Policy, Concept, Tools and Technuques. (CQ Press, 2001), hal. 80 
implementasi sebagai berikut ${ }^{12}$ :

a. Pembentukan unit organisasi baru dan pelaksana

b. Penjabaran tujuan ke dalam aturan pelaksana (SOP)

c. Pengoordinasian berbagai sumber dan pengeluaran pada kelompok sasaran, pembagian tugas di dalam serta di antara dinas-dinas dan badan pelaksana

d. Pengalokasian sumber untuk mencapai tujuan

\section{Merumuskan Kebijakan}

Merumuskan kebijakan memiliki tahapan-tahapan, dimana setiap tahapan akan saling berhubungan dan saling mempengaruhi. Sebagaimana yang dikutip Mudjia Rahardjo dalam bukunya Hough bahwa kerangka analisis kebijakan mencakup: 1) kemunculan isu dan identifikasi masalah, 2) perumusan dan otoritas kebijakan, 3) implementasi kebijakan, dan 4) perubahan atau pemberhentian kebijakan. ${ }^{13}$

Sebagaimana yang dikutip Hasbullah dari Ripley bahwa proses pembuatan kebijakan lahir dari siklus yaitu siklus pendek dan panjang. ${ }^{14}$

Tabel. 1.1 Siklus Perumusan Kebijakan Ripley

\begin{tabular}{|c|c|}
\hline Siklus Pendek & Siklus Panjang \\
\hline $\begin{array}{l}\text { 1. Penyusunan } \\
\text { agenda } \\
\text { pemerintah } \\
\text { 2. Agenda } \\
\text { pemerintah } \\
\text { 3. Formulasi dan } \\
\text { legitimasi } \\
\text { pemerintah } \\
\text { 4. Kebijakan }\end{array}$ & $\begin{array}{l}\text { 1. Penyusunan agenda pemerintah } \\
\text { 2. Agenda pemerintah } \\
\text { 3. Formulasi dan legitimasi kebijakan } \\
\text { 4. Kebijakan } \\
\text { 5. Implementasi kebijakan } \\
\text { 6. Tindakan kebijakan } \\
\text { 7. Kinerja dan dampak kebijakan } \\
\text { 8. Evaluasi terhadap implementasi, } \\
\text { kinerja dan dampak kebijakan } \\
\text { 9. Keputusan tentang masa depan } \\
\text { kebijakan (keputusan baru) }\end{array}$ \\
\hline
\end{tabular}

12 Robert L. Lineberry. American Public Policy. ( (New York: Harpen \& Row, 1978), 134

${ }^{13}$ Mudjia Rahardjo, Pemikiran Kebijakan... hal. 4

14 Hasbullah, Kebijakan Pendidikan... hal. 66 


\section{Permendikbud No. 17 Tahun 2017}

Tata cara penerimaan peserta didik baru (PPDB) termuat dalam Permendikbud No. 17 Tahun 2017. Untuk peraturan system zonasi diatur dalam Permendikbud No. 17 Tahun 2017 bagian empat pasa $15,16,17$ yang berbunyi:

Pasal 15

1) Sekolah yang diselenggarakan oleh pemerintah daerah wajib menerima calon peserta didik yang berdomisili pada radius zona terdekat dari sekolah paling sedikit sebesar $90 \%$ dari total jumlah keseluruhan peserta didik yang diterima

2) Domisili calon peserta didik sebagaimana yang dimaksud pada ayat 1 berdasarkan alamat pada kartu keluarga yang diterbitkan paling lambat 6 bulan sebelum pelaksanaan PPDB

3) Radius zona terdekat sebagaimana yang dimaksud pada ayat 1 ditetapkan oleh pemerintah daerah sesusi dengan kondisi di daerah tersebut berdasarkan jumlah ketersediaan daya tamping berdasarkan ketentuan rombongan belajar masingmasing sekolah dengan ketersediaan anak usia sekolah di daerah tersebut

4) Bagi sekolah yang berada di daerah perbatasan provinsi/kabupaten/kota, ketentuan prosentase dan radius zona terdekat sebagaimana dimaksud pada ayat 1 dapat diterapkan melalui kesepakatan tertulis antara pemerintah daerah yang saling berbatasan

5) Sekolah yang diselenggarakan oleh pemerintah darah dapat menerima calon peserta didik melalui:

a) Jalur presstasi yang berdomisili diluar radius zona terdekat dari sekolah paling banyak $5 \%$ dari total jumlah keseluruhan peserta idik yang diterima

b) Jalur bagi calon peserta didik yang berdomisili diluar zona terdekat dari sekolah dengan alas an khusus meliputi perpindahan domisili orangtua/wali peserta didik atau terjadi bencana alam/social, paling banyak 5\% dari total jumlah keseluruhan peserta didik yang diterima 
Pasal 16

1) SMA, SMK, atau bentuk lain yang sederajat yang diselenggarakan oleh pemerintah daerah provinsi wajib menerima peserta didik baru yang berasal dari keluarga ekonomi tidak mampu yang berdomisili dalam satu wilayah daerah provinsi paling sedikit $20 \%$ dari jumlah keseluruhan peserta didik yang diterima

2) Peserta didik baru yang berasal dari keluarga ekonomi tidak mampu sebagaimana dimaksud ayat 1 dibuktikan dengan surat keterangan tidak mampu (SKTM) atau bukti lainnya yang diterbitkan oleh pemerintah daerah

3) Apabila peserta didik memperoleh SKTM dengan cara yang tidak sesuai dengan ketentua perolehannya, akan dikenakan saknsi pengeluaran dari sekolah

4) Sanksi sebagaimana dimaksud pada ayat 3 diberikan berdasarkan hasil evaluasi sekolah bersama dengan komite sekolah, dewan pendidikan, dan dinas pendidikan privinsi sesuai dengan ketentuan perundang-undangan

Pasal 17

Ketentuan zonasi sebagaimana dimaksud dalam pasal 15 tidak berlaku bagi SMK. ${ }^{15}$

Berdasarkan paparan dari Permendikbud No. 17 Tahun 2017 ini dapat disimpulkan bahwa penerimaan melalui zonasi hanya di lakukan di tingkat SMP dan SMA sesuai dengan prioritas yang tercantum dalam peraturan. Seperti Jarak tempat tinggal, usia, nilai, prestasi dan lainnya. Namun kembali lagi bahwa setiap daerah diberikan kewenangan untuk mengelola pendidikannya. Seperti di daerah Yogyakarta, tidak hanya SMP dan SMA saja tapi tingkat SD sudah menggunakan system zonasi. Hal ini menandakan bahwa setiap daerah memiliki kewenangan dan karakterisitik berbeda, tergantung daerahnya masing-masing.

15 Permendikbud No. 17 Tahun 2017 


\section{Implementasi Kebijakan Sistem Zonasi}

Proses membentuk kebijakan tidaklah mudah. Membuat kebijakan cenderung dimanfaatkan untuk kepentingan politik dan birokratik. Mulai dari isu yang bermunculan kemudian berkemabang di public, lalu dimanfaatkan oleh partai politik untuk dinaikkan dan dibahas dalam lembaga legilslatif, sehingga menjadi kebijakan public. Kebijakan-kebijakan yang lahir kebanyakan dari ranah politik, seperti kebijakan dalam pendidikan. Seperti halnya seorang kepala daerah yang menjajikan SPP gratis untuk tingkat SD sampai SMA, ini salah satu contoh kebijakan yang lahir dari ranah politik. Hal seperti ini sudah menjadi hal yang lumrah di Indonesia

Sebagaimana dalam bukunya Mudjia Rahardjo bahwa Grindle menempatkan implementasi kebijakan sebagai suatu proses politik dan administrattif. Dengan memanfaakan diagram yang dikembangkan, jelas bahwa proses implementasi kebijakan hanya dapat dimulai apabila tujuan-tujuan dan sasaran-sasaran yang semula bersifat umum telah dirinci, program-program aksi telah dirancang dan sejumlah dana/biaya telah dialokasikan untuk mewujudkan tujuan-tujuan dan sasaran-sasaran tersebut. Ini merupakan sayarat pokok bagi implementasi kebijakan public apapun. ${ }^{16}$

\section{Proses Penerimaan Peserta Didik Baru}

Setiap lembaga pendidikan pasti menginginkan peserta didik yang berkualitas. Maka dari itu proses penerimaan peserta didik juga dilakukan dengan baik. Karena hal tersebut bagian dari manajemen peserta didik, mulai dari seleksi peserta didik masuk, orientasi siswa (MOS), dan ketika sudah lulus menjadi alumni. Beberapa hal yang perlu diperhatikan antara lain kriteria, persyaratan, prosedur, dan permasalah-permaslahan lainnya.

Meskipun peserta didik meemiliki hak yang sama untuk mendapatkan pendidikan, namun tidak semua peserta didik yang daftar diterima semuanya. Karena harus memperitimbangkan beberapa aspek. Selain itu ada beberapa persyaratan yang harus dipenuhi peserta didik. Kebijakan operasional dalam penerimaan

\footnotetext{
${ }^{16}$ Mudjia Rahardjo, Pemikiran Kebijakan Pendidikan... hal. 6
} 
peserta didik baru ini memuat tentang daya tampung peserta didik. Penentuan ini didasarkan pada kenyataan-kenyataan yang ada disekoah tersebut. Kondisi di sekolah meliputi jumlah daya tampung kelas, kriteria peserta didik yang diterima, sarana prasarana, anggaran yang tersedia, tenaga pendidik, jumlah peerta didik yang tinggal. Kebijakan ini juga membuat tentang seleksi dan penyaringan peserta didik. ${ }^{17}$

Badrudin dalam bukunya menyebutkan bahwa diantara permasalahan dalam penerimaan peserta didik diantaranya 1) adanya calon peserta didik yang memiliki hasil tes, nilai $\mathrm{UN}$, dan kecakapan yang sama dengan mereka yang ada pada batas bawah penerimaan, 2) adanya calon peserta didik yang memiliki kemampuan dibawah dari calon peserta didik lainnya, namun orang tua yang bersangkutan memiliki kekuasaan tertinggi di daerah tersebut. Ketika terbatasnya daya tampung sedangkan banyak calon peserta didik yang mempunyai kecakapan yang tinggi. $^{18}$

\section{Diskusi}

Pedoman penerimaan peserta didik baru pada satuan pendidikan yang diselenggarakan oleh pemerintah kota Yogyakarta tertuang pada Peraturan Walikota kota Yogyakarta No 23 Tahun 2019. Kota Yogyakarta hanya menyelenggarakan PPDB di dua jenjang, yaitu jenjang SD sedetajat dan Jenjang SMP sederajat, untuk jenjang SMA/SMK sederajat diselenggarakan oleh pemerintah provinsi Yogyakarta. Pada aturan sistem zonasi tahun 2019/2020 ini mengalami evalusi sebesar 90\% dari aturan tahun 2018/2019.

Aturan PPDB 2019/2020 pada jenjang SDN memiliki persyaratan sebagai barikut: 1 . Berusia 7-12 tahun pada tanggal 15 Juli 2019; 2. Jika pendaftar berasal dari dalam zona yang berarti satu wilayah kecamatan dengan sekolah yang dituju maka akan mendapatkan tambahan usia 180 hari, sedangkan jika pendaftar berasala dari luar zona yang berarti berasal dari luar wilayah kecamatan dengan sekolah yang dituju mendapatkan tambahan usia 120 hari; 3. Seleksi berdasarkan usia, dari yang

17 Badrudin, Manajemen Peserta Didik (Jakarta: Indeks, 2014), hal. $37-38$

${ }^{18}$ Badrudin, Manajemen Peserta Didik... hal. 38 
berusia tertua sampai dengan termuda sesuai daya tampung sekolah; 4. Urutan pilihan sekolah; 5. Waktu pendaftrana. Kota Yogyakarta memiliki 89 jenjang SDN, sesuai peraturan kepala dinas pendidikan kota Yogyakarta No:188/425 Tahun 2019 tentang petunjuk pelaksanaan penerimaan peserta didik baru pada satuan pendidikan yang diselenggarakan oleh pemerintah kota Yogyakarta pada tahun ajaran 2019/2020 menggunakan sistem Real Time Online (RTO).

Peraturan tersebut merupakan hasil dari perubahan pada peraturan pertama No : 188/635 pada tanggal 21 Mei 2019. Namun dari 89 jenjang SDN di kota Yogyakarta sekolah yang mampu mengimplementasikan sistem RTO pada proses PPDB hanya 41 sekolah, 48 sekolah lainnya masih menggunakan sistem offline dikarenakan fasilitas yang kurang mendukung. Di kota Yogyakarta sistem Zonasi telah diterapkan sejak tahun 2018, namun pada tahun ini sistem Zonasi di kota Yogyakarta mengalami evaluasi sebesar $90 \%$ dari tahun sebelumnya. Jika tahun 2018 sistem jalur dalam zonasi jenjang SMPN hanya memiliki 2 jalur yaitu jalur prestasi dan jalur zonasi wilayah, tahun ini mengalami evaluasi dan berkembang menjadi 4 jalur untuk dalam zonasi yaitu : 1. Bibit unggul, memiliki kuota maksimal 10\%, Bibit unggul merupakan siswa terbaik hasil dari seleksi nilai rapor semester $7,8,9,10, \& 11$ dan memiliki rekomendasi dari masing-masing SD calon peserta, selain seleksi rapor jalur bibit unggul juga menggunaakan seleksi nilai SKHUSBN 3 mata pelajaran yaitu bahasa Indonesia, matematika, dan IPA; 2. Zonasi Wilayah, jika pada tahun 2018 zonasi wilayah adalah zona prioritas $75 \%$, maka tahun ini zonasi wilayah memiliki kuota maksimal $30 \%$ sudah termasuk penyandang disabilitas sebesar 2\%; 3 . PPDB dari keluarga tidak mampu, memiliki kuota maksimal 10\%, jalur ini diperuntukkan bagi calon peserta didik dari kalangan tidak mampu, seleksi ini berdasarkan Nilai SKHUSBN 3 mata pelajaran, yaitu bahasa Indonesia, Matematika, \& IPA, selain SKHUSBN calon peserta didik diperbolehkan menggunakan tambahan prestasi non akademik, perbandingan nilai USBN setiap mata pelajaran yang tercantum pada SKHUSBN dengan urutan pertama bahasa Indonesia, urutan kedua matematika, urutan ketiga IPA; 4. Zonasi Mutu, memiliki kuota 40\% dan seleksinya sama seperti 
jalur PPDB dari keluarga tidak mampu. Dari semua jalur dalam zonasi calon peserta didik harus melampirkan kartu keluarga, ijazah, dan kartu ujian SD.

Untuk calon peserta didik di luar zonasi memiliki 2 jalur yaitu : 1. Jalur Luar Zonasi, memiliki kuota maksimal 5\% dan seleksi berdasarkan nilai SKHUSBN 3 mata pelajaran yaitu bahasa Indonesia, matematika, \& IPA, dan juga perbandingan nilai USBN tiga mata pelajaran tersebut yang tercantum pada SKHUSBN dengan urutan pertama bahasa Indonesia, urutan kedua matematika, urutan ketiga IPA; 2. Jalur Perpindahan Tugas \& Kemaslahatan Guru, memiliki kuota maksimum 5\%. Jalur ini diperuntukkan bagi calon peserta didik yang orang tuanya mengalami perpindahan tugas dari luar daerah ke kota Yogyakarta atau orang tua calon peserta didik mengajar di SMPN kota Yogyakarta. Sama halnya dengan jalur dalam zonasi, jalur luar zonasi juga harus melampirkan kartu keluarga, ijazah, dan no ujian SD calon peserta didik. Namun

permasalahan yang masih terjadi hingga saat ini dalam penerapan sistem zonasi tidak dapat dipungkiri, misalnya jalur zonasi yang memprioritaskan tempat tinggal masih sulit diterapkan, karena jumlah lulusan dengan ketersediaan sekolah dengan semua daerah belum seimbang. Akibatnya sekolah yang awalnya mendapatkan murid banyak menjadi terbatas, begitupun sebaliknya sekolah yang awalnya mendapatkan murid terbatas menjadi berlebih karena sekolah tersebut berada pada zona padat, sehingga calon peserta didik yang memiliki radius jauh akan kalah dengan calon peserta didik yang memiliki radius lebih dekat.

Selain itu juga berdampak pada jumlah kelas dan guru. Sekolah yang awalnya mendapatkan murid banyak menjadi terbatas akan kesulitan mengatur jam guru sehingga dapat menimbulkan pemutusan kontrak guru honorer. Sekolah yang awalnya mendapat murid terbatas menjadi berlebih akan kesulitan dalam pemenuhan sarana dan prasarana sekolah, selain itu juga jumlah guru yang kurang memadai. Selain permasalahan diatas kota Yogyakarta memiliki daerah blank spot yaitu daerah-daerah yang tidak terjangkau oleh SMPN manapun sehingga orang tua kesulitan untuk memasukkan anaknya ke sekolah negeri meskipun memiliki nilai bagus. 
Data penelitian menunjukkan ada beberapa wilayah di kota Yogyakarta memiliki jumlah sekolah negeri antara satu wilayah dengan wilayah lain tidak merata. Dampak positif sistem zonasi yang harus diakui yaitu; 1. Peserta didik yang berprestasi diharapkan dapat memotivasi peserta didik lainnya; 2. Guru yang memiliki kompeten akan dapat meningkatkan pembelajaran. Guru yang berkompeten maka akan ditugaskan untuk mengajar siswa yang memiliki prestasi rendah; 3. Terciptanya pemerataan kualitas pendidikan, anak-anak memiliki kesempatan yang sama dalam mendapatkan pendidikan yang berkualitas; 4 . Sistem zonasi secara ekonomis dapat menghemat biaya transport dan keefektifan waktu serta mendekatkan anak dengan lingkungan keluarganya. Implikasi lainnya program zonasi memberikan dampak lingkungan seperti meminimalisir kemacetan lalu lintas, polusi udara, kesehatan anak, dan meminimalisir ketergantungan pada kendaraan bermotor. Secara tidak langsung sistem ini juga mendorong peserta didik untuk berjalan kaki atau menaiki sepedah karena jarak sekolah dan tempat tinggal yang tidak jauh

\section{Kesimpulan}

Berdasarkan hasil penelitian dan pembahasan yang telah dilakukan dapat diperoleh kesimpulan yaitu kebijakan sistem zonasi berasal dari upaya pemerintah untuk mewujudkan pemerataan pendidikan agar dapat meningkatkan kualitas pendidikan di Indonesia. PPDB sistem zonasi diterapkan pertama kali di kota Yogyakarta pada tahun 2018/2019, lalu mengalami perubahan evaluasi sampai $90 \%$. Dalam penerapan sistem zonasi ada beberapa dampak positif diantaranya Peserta didik yang berprestasi dapat memotivasi peserta didik lainnya, guru yang memiliki kompeten akan dapat meningkatkan pembelajaran, terciptanya pemerataan kualitas pendidikan, secara ekonomis dapat menghemat biaya transport dan keefektifan waktu serta mendekatkan anak dengan lingkungan keluarganya. Namun kendalan dalam penerapan sistem ini diantaranya jumlah lulusan dengan ketersediaan sekolah dengan semua daerah belum seimbang sehingga berdampak pada jumlah kelas dan guru. 


\section{Daftar Pustaka}

Abidin, Muhammad Zainal dan Asrori. 2018. "Peranan Sekolah Kawasan Berbasis Sistem Zonasi dalam Pembentukan Karakter di SMP Negeri 15 Kedung Cowek Surabaya". Jurnal Pendidikan Islam. Vol. 7 No. 1

Arif Rohman dan Teguh Wiyono, 2012, Education Policy In Desentralization Era, Yogyakarta: Pustaka Pelajar

Badrudin, 2014, Manajemen Peserta Didik, Jakarta: Indeks

Bintoro, Ratih Fenty A. 2018. "Persepsi Masyarakat Terhadap Implementasi Kebijakan Zonasi Sekolah dalam Penerimaan Peserta Didik Baru (PPDB) Tingkat SMA Tahun Ajaran 2017/2018 di Kota Samarinda. Jurnal Riset Pembangunan. Vol. 1 No.1

Gupta K. Dipak, 2001, Analyzing Public Policy, Concept, Tools and Technuques. CQ Press

Tilaar, H.A.R dan Nugroho, Riant, 2010, Kebijakan Pendidikan: Pengantar Untuk Memahami Kebijakan Pendidikan dan Kebijakan Pendidikan sebagai Kebijakan Publik, Yogyakarta: Pustaka Pelajar

Hasbullah. M, 2015. Kebijakan Pendidikan (Jakarta: RajaGrafindo Persada

Creswell, John W. 2017. Research Design: Pendekatan Metode Kualitatif, Kuantitatif, dan Campuran. Yogyakarta: Pustaka Pelajar

Lineberry , Robert L, 1978, American Public Policy, New York: Harpen \& Row

Mandic, S., Et.Al, 2017. "I Wanted To Go Here": Adoloescents' Perspectives on Shool Choice, (Journal of School Choice, 12 (1) Permendikbud No. 17 Tahun 2017

Rahardjo, Mudjia, 2010, Pemikiran Kebijakan Pendidikan Kontemporer, Malang: UIN Maliki Press 
Rusdiana. 2015. Kebijakan Pendidikan Dari Filosofi ke Implementasi. Bandung: CV Pustaka Setia

William N Dunn, Pengantar Analisis Kebijakan Publik, terj. Samodra Wibawa dkk

Wulandari, Desi, dkk. 2018. "Pengaruh Penerimaan Peserta Didik Baru Melalui Sistem Zonasi Terhadap Prestasi Belajar Siswa”. Jurnal Kultur Demokrasi. Vol 5 No 9 